\title{
ESTRATÉGIAS DE INSERÇÃO NA LITERATURA 2.0
}

\author{
Bruno Lima Oliveira
}

\begin{abstract}
RESUMO
Este ensaio objetiva mostrar algumas estratégias de inserção no circuito literário por jovens diletantes amadores. Até chegar à publicação impressa, e uma suposta legitimidade literária do escritor, são cada vez mais comuns os blogs servindo como exercício literário e inserção do autor e texto junto ao grande público, como são exemplos Santiago Nazarian, João Paulo Cuenca, Ivana Arruda Leite e Clarah Averbuck.
\end{abstract}

PALAVRAS-CHAVE: Blog; circuito literário; autoficção.

$\mathrm{N}$

o dia 30 de julho de 2013, o escritor Santiago Nazarian, em seu perfil no Facebook, publicou o seguinte comentário:

Ei, por que Mastigando Humanos é leitura obrigatória no vestibular da Paraíba e eu nunca fui pra Paraíba? Tem gente mosqueando que poderia organizar um bate-papo meu com os alunos por lá. Aliás, tem gente mosqueando que poderia me convidar para bate-papo em tantos lugares do Brasil... Ainda sou autor vivo e ativo, altivo atuante e operante, tá? Só pra avisar...

1 As citaçôes serão transcritas ipsis litteris. Disponível em https://www.facebook.com/ santiagonazarian?fref=ts. Acesso em 30 de julho de 2013. 
Cinco horas após esta publicação, 112 pessoas a haviam "curtido", houve 35 comentários e outros três compartilhamentos, aumentando o alcance das palavras do escritor "vivo e ativo". Ainda no Facebook, descobrimos que Nazarian possui, em sua rede de relacionamentos, 3239 amigos, entre amizades virtuais e presenciais, mas o que importa, sobretudo, é que as palavras do escritor atingem um público para além dos leitores de seus livros, isto é, sua persona é formada com o auxílio de discursos alheios ao literário. Não é possível fazer um levantamento do número exato de seu público leitor, salvo uma aproximação estimada baseada na quantidade de exemplares vendidos pela editora etc. No entanto, o que chama a atenção nesse comentário queixoso do autor é a lembrança de que ele está disponível, e é o próprio Nazarian quem faz questão de dar o recado, pois avisa que é "atuante e operante".

Santiago Nazarian, além de seus amigos no Facebook, possui também um blog, intitulado Jardim Bizarro, cujo endereço é http://www.santiagonazarian.blogspot.com.br/. Seu blog mistura impressóes e experiências empíricas de sua vida, como viagens realizadas e as respectivas fotografias, e trechos de livros, como o de seu próximo romance, por exemplo. Percebe-se, rapidamente, que o autor se vale de mais de um veículo midiático para uma performance, nos quais pode, também, divulgar sua produção literária. A recepção da persona autoral, por parte do público, acontece em mais de um canal, e todos eles se retroalimentam, compondo um sujeito híbrido e (extra)literário. Mas por que se preocuparia com essa autopromoção o autor se ele é publicado por uma grande editora e já é, inclusive, um escritor premiado?

A resposta foi dada por outro escritor com seu lugar ao sol já devidamente alcançado - João Paulo Cuenca. Em 2010, no evento "Café Literário: Literatura na web”, com Juliana Krapp, Manoela Sawit e o próprio Cuenca, realizado na Biblioteca Popular de Botafogo, o autor de Corpo presente, ao dizer que desde criança nutria o desejo de ser escritor, afirmava que, para tanto, era necessário participar de eventos, ir a universidades, dar entrevistas (sic). Dizia ele que ser escritor não se limitava a escrever e que, para poder realizar seu ofício, essas demais atividades se faziam importantes. $\mathrm{O}$ que ele pretendia dizer, a meu ver, equivale a afirmar que o escritor contemporâneo precisa criar uma imagem de si próprio para se tornar conhecido; necessita, principalmente, se autopromover, de maneira a performar uma identidade pública - não necessariamente autobiográfica - para, então, ingressar no circuito literário e 
conquistar o espaço biográfico, termo cunhado por Leonor Arfuch [2010], sem o qual, dificilmente, despertaria o interesse de uma editora e consequentes leitores. Em uma palavra, o escritor contemporâneo é performático e se constitui como personagem de si mesmo. Bem como Nazarian, Cuenca também possui uma página no Facebook, com 1929 seguidores, e é blogueiro, embora seus vários blogs estejam todos desatualizados.

Percebe-se, nesse rápido introito, uma das razões para a crítica literária abandonar a morte do autor postulada pelos formalistas e estruturalistas e olhar com mais atenção para a figura do escritor, não de forma a buscar um biografismo que explicaria a obra, mas porque é cada vez mais comum uma performance autoral que se mistura à ficção, mesclando relatos autobiográficos e empíricos à fabulação - a autoficção. Atualmente, em um mundo cada vez mais midiático e imagético, o escritor excede o ato de escrever como seu ofício, como bem apontou João Paulo Cuenca. Ao participar de feiras literárias, programas de televisão, lançamentos de livros, congressos, palestras etc., o escritor dá-se a conhecer, assume uma voz e um corpo, torna-se uma pessoa pública - não está mais morto, em síntese. É comum, inclusive, como já indicou Philippe Lejeune [2008], que o leitor conheça o autor sem nada dele ter lido, isto é, sua literatura tem se mostrado menos importante, em certo sentido, do que sua própria persona.

Também foi Lejeune [2008] quem disse que, antigamente, a leitura da obra suscitava o desejo do leitor de conhecer o autor, ao passo que, agora, devido ao grande número de entrevistas e à exposição midiática, isso se inverte, é a figura pública do autor que desperta o interesse em sua literatura. Portanto, hoje, o autor assume a função primordial de se valorizar, de ser seu próprio promoter, por assim dizer. Nada mais natural, nesse sentido, que Nazarian, ao saber da leitura de seu romance para o vestibular da Paraíba, faça questão de lembrar que está disponível para um bate-papo com alunos-leitores. É claro que este interesse não diz respeito apenas ao aspecto mercadológico, como pode parecer indicar, mas é comum autores variados afirmarem que é importante e prazeroso o diálogo com jovens leitores, pois estes não teriam o cacoete do público mais experiente nem tampouco se censurariam em perguntar questóes jamais levantadas em eventos do porte da Flip (sic), como mencionou Daniel Galera recentemente no evento "Encontros Literários”, mediado por Guilherme Freitas, também na Biblioteca Popular de Botafogo, no dia 31 
de julho de 2013. A participação dos escritores contemporâneos em eventos de e sobre literatura é tão intensa, atualmente, que dois exemplos, até aqui, já foram utilizados e mais ainda podem surgir ao longo do ensaio. Destarte, o fetiche em torno do autor - sempre presente, mesmo quando da leitura imanente da obra literária - ganha força, como já bem apontou Ana Cláudia Viegas [2007].

Neste contexto, o autor Santiago Nazarian sobreviveria ao esquecimento público? Sua literatura continuaria a ser lida com seu repentino "desaparecimento"? Se é o autor o responsável, hoje, por fomentar o desejo dos leitores pelo texto, mesmo uma carreira relativamente bem-sucedida correria o risco de caminhar para o ostracismo. Sérgio de Sá, nessa direção, afirma que "esse é o perigo quando ser escritor torna-se mais importante do que escrever" (SÁ, 2010, p.151). Não esqueçamos que a literatura é arte e, como tal, reivindica mais tempo, dedicaçáo e disciplina do que os gastos com entrevistas e autopromoção. Sérgio de Sá prossegue sua crítica ao dizer que, "na sociedade pós-industrial, o escritor é cada vez mais uma imagem. A obra fica em segundo plano" (SÁ, 2010, p.155).

Esta imagem construída de um escritor-personagem ou personagem-escritor se dá em várias frentes, como já assinalado. Leonor Arfuch [2010] e Sérgio de Sá [2010] privilegiam a relação presente na construção identitária do autor nas entrevistas, mas estas não são as únicas tampouco a de nosso maior interesse aqui. Santiago Nazarian e João Paulo Cuenca são dois autores que têm uma relação estreita com blogs - prática cada vez mais comum entre escritores - e com a utilização da internet como forma da criação de uma persona. Muitos outros exemplos há e poderia ficar cansativo elencar todos os escritores brasileiros que, concomitantemente ao lançamento de livros publicados por grandes editoras, com reconhecimento de público, sucesso editorial e pesquisados pela Academia, iniciaram suas carreiras em blogs e/ou ainda mantêm a prática blogueira mesmo após seu sucesso constituído. A fim de evitar uma enumeração extenuante, restringirei o número a apenas duas autoras: Ivana Arruda Leite e Clarah Averbuk, também adeptas do Facebook.

As duas servem-me como corpus de trabalho por razóes que, dialeticamente, se aproximam e se distanciam. A primeira começou a publicar tarde, depois de incansáveis tentativas frustradas de envio de originais para editoras, até que Marcelino Freire intercedeu a seu favor e ela finalmente 
conseguiu sua primeira edição, conforme anunciou no encontro realizado em maio de 2013 em São Paulo, com Luiz Bras e Mona Dorf, referente ao programa "Encontros com autores e ideias". Segundo Ivana, foi bom ter recebido tantas recusas, pois isso fez com que ela continuasse a escrever e aperfeiçoasse sua literatura (sic). Quanto aos blogs - tema do encontro -, a autora de Eu te darei o céu e outras promessas dos anos 60 diz que só não abandona completamente os diários virtuais porque lá estão contidos todos os seus contos, inclusive os de livros já esgotados. Complementa seu desânimo ao afirmar que os blogs já estão ultrapassados, que o Facebook é muito mais dinâmico e, portanto, cativa mais os leitores; apesar disso, no entanto, não abandona o seu Doidivanas, cujo endereço é http://doidivana.wordpress. $\mathrm{com} /$, embora ele não seja um blog estritamente literário, o que, em certo sentido, ajuda na construção da identidade autoral, uma vez que os leitores mais e mais fetichizam sua figura. Questionada se ela é também leitora de blogs, respondeu que lê apenas os blogs de amigos (sic), o que denota uma espécie de maior dificuldade de acesso ao circuito literário àqueles blogueiros diletantes, ainda alheios ao universo mercantil da literatura e à legitimação editorial. Como um blogueiro poderia obter a intervenção de um autor já conhecido, como foi o caso da própria Ivana, se a atenção reside apenas ao já formado e seleto grupo de amigos?

Clarah Averbuck talvez seja o nome mais emblemático e contundente no que se refere à prática blogueira. Diferentemente de Ivana, começou sua carreira literária cedo e chegou ao livro impresso após desenvolver sua escrita nos blogs. A nomenclatura "literatura de blog", no entanto, sempre incomodou a autora de Máquina de pinball, que insistia serem os diários virtuais apenas um meio para a publicação, dispensando editores e aproximando autor e leitores. A dificuldade enfrentada por Ivana Arruda Leite de conseguir ser publicada foi facilmente contornada por Clarah Averbuck ao escrever o que bem entendesse em seus blogs. Dona do blog, era ela senhora inconteste de seu meio de publicação, libertando-se da necessidade de satisfazer o mercado editorial. Contudo, ocorre um caso interessante e paradoxal no salto do blog para o livro impresso, no caso de Averbuck. Se aquele não passava de um meio de publicação, como ela insistia em dizer, muitas vezes irritada com a persistência nesse assunto, por que razão publicar também em livro? O que o texto apresentaria de diferente se o que estava em questão era apenas o meio 
em que ele fora escrito? Seria a edição impressa um legitimador tanto do texto quanto do autor, no sentido de que qualquer um pode criar um blog e escrever o que bem entender, ao passo que, para se ter a publicação impressa por uma grande editora, haveria a necessária submissão a um corpo editorial e à chancela de literatura? A autora blogueira defendia-se argumentando que não via nada de inusitado em lançar um livro como uma coletânea dos melhores posts de seu blog, pois havia coletâneas de poemas, contos, crônicas, cartas e até diários póstumos eram publicados também. Por que com o blog haveria de ser diferente? E não foi. Seus dois primeiros livros foram resultado de uma bricolagem de textos escritos originalmente na internet e textos produzidos com a finalidade da edição impressa. A meu ver, o que boa parte dos blogueiros almeja, como parece ter sido o caso de Averbuck, é o reconhecimento editorial, o lançamento de seus textos em livro, como se essa fosse a única forma de alcançar o status de literatura. Cada vez mais os blogs são corpus de pesquisas acadêmicas e alvo de "caçadores de talentos", mas ainda são, de certa forma, estigmatizados como escrita descartável e pouco ou nada estetizada.

Etimologicamente, blog é a junção dos termos web (página na internet) e $\log$ (diário de bordo), que em sua composição já aponta para uma explícita contradição. Os diários escritos em cadernos e/ou agendas, via de regra, encerravam em si segredos inconfessáveis a possíveis leitores, ao passo que os blogs são escritos na internet de modo a expor, para qualquer pessoa, suas idiossincrasias. Esta é, porém, uma incoerência apenas aparente, pois os textos em primeira pessoa não são mais reveladores de uma verdade biográfica capaz de expor alguma intimidade assaz comprometedora; as escritas de si da atualidade, em especial a autoficção, seja em blogs ou em livros, indiciam uma verdade outra, nem mais estritamente empírica, muito menos apenas ficcional. Os textos que circulam na internet, normalmente, são escritos em uma primeira pessoa performática, que se constrói de modo a suscitar no leitor aquele desejo de conhecer a obra a partir do eu que se cria. Desse modo, o pacto autobiográfico de Lejeune [2008] tornou-se obsoleto se pensarmos o indivíduo contemporâneo à luz do conceito de autoficção proposto por Diana Klinger, que o desenvolve "a partir da crítica à noção de representação (Derrida) e de sujeito (Nietzsche)" (KLINGER, 2007, p.49), e Luciene Azevedo, que, como alternativa ao pacto autobiográfico, sugere o pacto autoficcional, que "pressupóe sempre a ambiguidade da referência, a sutileza da imbricação 
entre vida e obra, um leitor sempre em falso, driblado pela desestabilização de uma escrita de si em outros" (AZEVEDO, 2007, p.48).

Santiago Nazarian, João Paulo Cuenca, Ivana Arruda Leite e Clarah Averbuck são escritores devidamente editados e adicionados ao cânone em formação da literatura brasileira contemporânea. Aqui, não está em questão se os quatro são adeptos da autoficção, se praticam uma prosa híbrida composta por realidade e ficção de modo a tornar indecidíveis seus limites. O propósito deste ensaio é aproximá-los por outro viés - o de personalidades públicas. Como tais, são reconhecidos no meio literário, nas faculdades de Letras, em programas de televisão, em feiras literárias e em redes sociais, mesmo que aqueles que os reconheçam não sejam seus leitores - e jamais venham a ser. Os quatro, enfim, assumem para si a condição pública de escritores, formada em cada uma das suas apariçóes, presenciais ou virtuais. Consciente ou inconscientemente, estes autores criam uma identidade que, de alguma maneira, os identifica a um público, leitor ou não - não nos esqueçamos de que Roland Barthes, apesar de defender a morte do autor, admitia-o "nos manuais de história literária, nas biografias de escritores, nas entrevistas dos periódicos, e na própria consciência dos literatos, ciosos por juntar, graças ao seu diário íntimo, a pessoa e a obra" (BARTHES, 1988, p.66). Atualmente, o diário íntimo ao qual se referia Barthes é substituído pelos blogs e pelas redes sociais, capazes de "devassar" a intimidade dos autores e suscitar o desejo do leitor voyeurista pela vida empírica da personalidade literária. Quando a primeira pessoa assume relevância em sua prosa de ficção, seja nos blogs, seja na literatura impressa, o cotejo entre vida e obra torna-se mais interessante para o leitor, iludido por um narrador performático, autoficcional.

Ana Cláudia Viegas é muito precisa ao situar o autor em nosso cenário midiático e rediscutir o estruturalismo. Para a pesquisadora, "ao lermos um texto, não temos apenas o nome do autor como referência, mas sua voz, seu corpo, sua imagem veiculada nos jornais, na televisão, na internet. A obsessão contemporânea pela presença nos afasta da concepção barthesiana desse autor como 'um ser de papel'” (VIEGAS, 2007, p.18, grifo do original). Eu acrescentaria que essa presença restrita à internet nos aproxima do autor sem necessariamente nos colocar em contato com sua literatura, como ocorre nas redes sociais. Nestas, lemos fragmentos de discursos e curiosidades da "vida privada" do autor; vemos seleção de fotografias e demais particularidades intimas e 
ainda temos a possibilidade de interação dialógica. Por outro lado, porém, os blogs nos aproximam de maneira mais estreita, posto que a familiaridade se dá textual e (auto)ficcionalmente, ou seja, é possível esmiuçar o texto de maneira a encontrar ali semelhanças com a persona fragmentada que se constrói em momentos estanques e isolados: entrevistas, redes sociais, apariçóes públicas, conferindo ao fato episódico o status de narrativa acabada, sem falar que a ficção, como reza o senso comum, revela mais sobre a vida do escritor do que uma autobiografia, por exemplo. É nesse sentido que os blogs nos vinculariam mais à persona construída discursivamente pelo escritor - persona esta deveras fomentada nas redes sociais, numa espécie de construção identitária ininterrupta e en âbime.

É possível que a individuação autoral seja, além de uma maneira inicial de se tornar conhecido e angariar leitores, uma forma de crítica justamente à necessidade narcísica e voyeurística da nossa sociedade, uma vez que não é mais possível pensarmos o sujeito de forma una, inteira, coesa, como o eu das Confissóes de Rousseau, mas sim de maneira fragmentária, híbrida, indefinível, autoficcional. Há outras hipóteses que buscam embasar teoricamente a presença de narradores em primeira pessoa autoficcionalmente, mas não me ocuparei delas aqui.

No momento, interessa pensar como os blogs impulsionam escritores ainda desconhecidos para o ambiente literário e suas estratégias de inserção no circuito. Os autores supramencionados são todos já devidamente conhecidos, portanto, para uma verificação do processo de reconhecimento ao qual almeja um blogueiro, é pertinente recorrer a um "anônimo". A estética do comum vem sendo estudada por ensaístas do gabarito de Denilson Lopes [2012] e Silviano Santiago [2011]. Este último, a respeito da obra de Lygia Clark, afirma que,

agora, o homem comum começa a chegar à posição de artista. Nunca o homem esteve táo perto de sua plenitude: ele não tem mais desculpas metafísicas. Não tem mais nada sobre o que possa projetar-se. Está livre da irresponsabilidade. Não pode mais nem mesmo negar-se como ser total. Já que nenhuma transferência é mais possível, resta-lhe viver o presente, a arte sem arte, como uma nova realidade (SANTIAGO, 2011, p. 27-8). 
E, inversa e paradoxalmente, Silviano também afirma que o artista encaminha-se para o status de homem comum. Essa dialética já foi apontada por Walter Benjamin [1994] no momento em que o pensador refletia que os leitores, ao escreverem para os jornais, assumiam a posição também autoral. No que diz respeito ao blogs, cada vez mais é usual que diletantes amadores se valham desse meio de publicação para se autodenominarem autores igualmente, ao mesmo tempo em que os escritores reconhecidos como tais, democraticamente, utilizam o espaço virtual para escreverem.

Dentro do universo infinito de blogs literários na internet, pincei o Resultado Desastroso (http://resultadodesastroso.blogspot.com.br/), escrito pela ainda aspirante a escritora profissional Mariana Bernardes, e que servirá para analisarmos as estratégias empregadas pela autora com o intuito de se afirmar uma escritora e se tornar conhecida, aumentando seu número de leitores e ambicionando a publicação impressa.

Inicialmente, quando o li pela primeira vez, duas coisas me chamaram a atençấo: i) ser um blog apenas de poemas - e alguns bons poemas, diga-se de passagem - e ii) escrito por uma poeta muito jovem, com aproximadamente 17 anos. Passei a acompanhar com bastante regularidade seus poemas e resolvi lhe perguntar como surgiu o interesse pela poesia. A resposta que obtive foi a de que seu pai sempre foi um amante dos versos e a incentivava a escrever desde pequena.

No blog, os poemas, com o tempo, cederam espaço para a prosa e, posteriormente, também foram publicados em livro, em maio de 2013, por uma editora que trabalha com tiragem por demanda, intitulado Demasias. Abaixo, o poema que dá título ao livro, em um post do dia 2 de abril de 2013:

\section{Demasias}

Cresci assim:

Exagerada.

Por vezes me sentia demais

Até quando queria sentir nada.

Vivi mais do que deveria

Em um tempo desarranjado.

Me criei desarranjada. 
Tentei me encontrar fazendo de tudo

Fui o mais fundo que poderia chegar,

Ceguei.

Em um repentino despertar,

vi-me desesperada.

Mudei, mudei e continuarei mudando

Mas no meio disso encontrei um lar:

As palavras, a poesia.

Desde então vivo

E dou vida à tudo em

Demasia.

O poema desnuda um sujeito perdido, angustiado, cego, desesperado até o encontro com as palavras, com a poesia. E esta encontra abrigo, num primeiro momento, no blog, ou melhor, ela nasce na internet, tem sua primeira publicação no diário virtual, que não vem a ser um resultado desastroso por dois motivos iniciais: o primeiro porque foi lida, ou seja, o blog cumpriu seu papel de espaço para publicação, como diria Averbuck; o segundo porque redundou em livro, recebendo, ainda que de forma insatisfatória, haja vista a nenhuma publicidade e a tiragem diminuta da primeira edição, a legitimação da impressão. Do mesmo modo que a poesia nasce na internet, é no espaço virtual que a persona da blogueira encontra fertilidade para surgir e se autoficcionalizar, performando uma identidade autoral e plural.

Apesar de ser um livro de poesia o primeiro fruto material do ambiente virtual de Mariana Bernardes, é com a prosa que ela melhor exemplifica a necessidade de se reconhecer como escritora e a angústia de perceber a ausência de "portas abertas" para um empreendimento que, à primeira vista, teria sido bem-sucedido. Se por um lado a edição impressa legitima o mesmo texto publicado anteriormente no blog, por outro ainda não é suficiente. É muito fácil qualquer autor lançar um livro hoje porque são muitas as editoras por demanda e as condições de pagamento são razoáveis, isto é, para um texto ser publicado, ele não precisa mais, dependendo da editora, naturalmente, ser aprovado por um conselho editorial; sua "qualidade literária" está em segundo plano e o mais importante é que a mercadoria "livro" dê o retorno financeiro esperado. Penso que o sucesso da jovem blogueira teria sido completo - isso 
ainda pode se dar - caso ela conseguisse ingressar no circuito literário e alcançasse o espaço biográfico, concedendo entrevistas e atingindo a grande mídia. Quais foram suas estratégias para atingir esse objetivo?

Houve grandes mudanças iniciais no Resultado Desastroso. O primeiro diz respeito ao layout do blog, originalmente ilustrado com várias caveiras, talvez em diálogo com o próprio título. Estas cederam espaço para um fundo menos mórbido e mais lúdico, suscitando no leitor uma outra imagem da escritora. A poesia foi substituída pela prosa - pequenas crônicas de sua vida corriqueira, como se ela buscasse, através de uma nova performance, angariar mais e variados leitores. Os posts em prosa narram o dia a dia de Mariana, evidenciando o voyeurismo e, sobretudo, o exibicionismo de nosso tempo. Evidentemente, o leitor não tem como saber se os episódios narrados ocorreram de fato, mas, autoficcional ou autobiograficamente, a persona autoral é mais explicitamente construída. Em diálogo com a blogueira, fui informado de que ela pretendia escrever sobre as coisas que acontecem a uma adolescente para que os demais jovens de sua idade se identificassem com ela e assumissem as histórias como suas também. Nada ingênua essa artimanha para alguém de sua idade.

Estas, porém, não foram as únicas modificações com o intuito de ampliar seu público leitor. Ela passou a, eventualmente, publicar entrevistas feitas com algumas pessoas ligadas à literatura e às artes em geral, como o poeta e também blogueiro Flávio Corrêa de Mello, o artista plástico Solano Guedes e a escritora e blogueira Thereza Christina Rocque da Motta. Mariana Bernardes, em texto intitulado "Escritores sem vergonha", postado no dia 3 de abril de 2013, reflete sobre o que necessita um escritor:

Nas últimas semanas, em uma tentativa de dar um up no meu querido blog, comecei a fazer entrevistas, comecei a me comunicar com editoras, outros blogs, sugerir parcerias e coisas desse tipo. Nas entrevistas, em particular, sempre faço uma pergunta: $\mathrm{O}$ que um escritor precisa ter? E pensando aqui, na minha varanda, dia após dia, cheguei à uma conclusão.

Quando comecei a escrever o blog, há uns cinco anos, achava que escritores precisavam ser pessoas muito cultas e intelectuais. Depois de uns dois anos comecei a achar que escritores, poetas 
principalmente, precisavam ser muito tristes e infelizes, pois era o que funcionava para mim. (...)

Comecei as crônicas, já em uma fase ranzinza, crítica e sarcástica. Eis que me veio uma realização: é isso que quero ser quando crescer! Não quero ser médica, atriz e nem mesmo jornalista. Quero ser escritora. Com isso em mente, dúvidas e mais dúvidas. A maior delas sempre foi: o que um escritor realmente precisa ter para dar certo? Minha resposta é muita falta de vergonha na cara.

(...) É preciso meter a cara, enviar manuscritos, crônicas e poesias sem medo de receber não's, pois eles vêm. É necessária certa exposição, pois escrever, pelo menos para mim, sempre foi me mostrar sem medo, me colocar inteira em poucas ou muitas palavras sem ter vergonha das partes mais obscuras de mim. Talvez seja isso que os novos escritores precisem: falta de vergonha na cara e um blog para postarem seus devaneios. Então, queridos amigos, falo aqui para toda a internet e que fique registrado por toda a eternidade: Sou uma escritora sem vergonha! [Grifo meu]

O texto acima é bastante pertinente e exemplar para o propósito deste ensaio. Inicialmente, a blogueira parte de uma imagem de escritor construída por si própria enquanto leitora, ou seja, sua escrita, a priori, já nasce com a preocupação extratextual, com um olhar atento para o que deve ser um escritor ou poeta, independentemente do conteúdo literário. De acordo com Mariana, generalizando seu conceito, há uma visão estereotípica do mundo das letras e, pensando nela, buscava uma performance que a distinguisse dos demais, ou, ao menos, os equiparasse. Ao dizer que "escritores precisavam ser pessoas muito cultas e intelectuais" e idealizar entrevistas com seus pares, ela imiscuía-se no universo do qual quer fazer parte. Consciente de que ainda precisa galgar um percurso arenoso, porém, declara que são necessários "falta de vergonha na cara e um blog para postarem seus devaneios". E finaliza reconhecendo-se "uma escritora sem vergonha". Mas se ela já é uma escritora, o livro serviria apenas como um legitimador? Por que o blog não se basta? Haveria algum prejuízo canônico para a admissão dos textos publicados em 
blogs serem considerados literatura? Lembremo-nos de que os modernistas, que questionaram o cânone vigente à época, dele fazem parte hoje.

As entrevistas publicadas no Resultado Desastroso, penso eu, além de tornar, a seu ver, o blog mais interessante, ajudavam a construir para si a performance de uma pessoa mais concatenada e mais enturmada com nomes do meio ao qual ela pretendia ter acesso. Até o momento, porém, foram as únicas três entrevistas. $\mathrm{Na}$ minha opinião, este é um excelente exemplo da preocupação de Sérgio de Sá [2010], pois o blog que continha boas poesias, que renderam inclusive uma publicação impressa, abdicou de textos autorais para dar voz a terceiros. É claro que, na condição de entrevistadora, Mariana Bernardes também estava textual e ficcionalmente presente, todavia não mais como protagonista. Ademais, qualitativamente, sua prosa está aquém da sua poesia.

Finalmente, como último recurso em busca de autopromoção, como vários escritores já fizeram, a jovem e ambiciosa blogueira criou uma página no Facebook para o seu blog e atingiu o número de 2540 pessoas "curtindo" seu diário virtual. Esse número ainda não the rendeu, ao que parece, o resultado esperado, mas não é nada de desastroso, principalmente se pensarmos, como Averbuck, que ela está sendo lida, apesar de num meio de publicação virtual, ou seja, sem a legitimidade esperada.

Textualmente, ela fornece bons exemplos de sua inquietação em se tornar uma escritora, evidenciando que o ato de escrever em blogs não lhe confere tal posição. No dia 20 de maio de 2013, ela escreve "Diário de notas sem texto", no qual diz:

A rede social consiste em escrever para si mesmo esperando que alguém vá responder ou replicar seus devaneios particulares. (...) Seguindo a linha da honestidade que prometi há duas notas atrás, irei confessar uma coisa: escrevo para ser lida. Não irei perpetuar a mentira de que escrevo para mim, pois desde que comecei a escrever mantenho um blog que faço bastante questão de divulgar.

É explícita a diferença entre os diários íntimos mencionados por Barthes e os diários virtuais deste século, quando escreve-se em busca de leitores e esforça-se para alcançá-los. Para isso, uma estratégia comumente empregada 
pelos blogueiros que ainda não possuem leitores fiéis é avisar, via redes sociais, que há um novo texto disponível à espera de leitura. Como visto no caso de Nazarian, um simples comentário em seu perfil do Facebook pode se multiplicar através das redes de amizades que se intercomunicam.

Três dias antes do post acima, Mariana escreveu um outro, homônimo:

Toda a minha personalidade consiste em ser mais uma pobre jovem rica, perdida em suas pretensóes e com a insistente mania de ser pouco realista, apesar de extremamente crítica. Comę̧o a escrever essas notas despida de personagens. Aqui represento a mim mesma, perdida nos meus quase vinte anos e no, ouso dizer, inferno de ser jovem nessa geração. Não pretendo mentir nas notas que se seguem, o que eventualmente pode acontecer, então comę̧o contando uma verdade vergonhosa: tenho o sonho secreto de ser uma voz da geração que tanto afirmo detestar. Como já disse, aqui não sou nenhum personagem e me atrevo a escrever à mão em uma folha sem linhas.

Como a maioria da minha idade sonho com uma carreira financeiramente inviável, o que desagrada secretamente meus pais. Quero escrever livros, eles querem que eu seja jornalista. (...)

Aprendi quando pequena que não é de bom tom falar muito sobre si, então apesar de escrever notas completamente biográficas e um blog, vou fingir ser um exemplo de etiqueta e parar antes de me tornar rude. [Grifo meu].

Apesar de "pouco realista", a autora se despe de personagens, embora mantenha a caracterização de uma personagem-escritora ou escritora-personagem, porta-voz de sua geração. Sua ambição é a de "escrever livros", ou seja, a escrita em blogs ou "à mão em uma folha sem linhas", ou ainda a jornalística, mesmo com enorme circulação, como é o caso de vários periódicos, não lhe agrada. O desejo está nos livros. São eles, mesmo para alguém que publica regularmente na internet, que conformam um escritor.

Para ela, a realidade é complicada, motivo suficiente para seguir a lição aprendida quando criança e, paradoxalmente, falar de si, já que se autoficcio- 
naliza. As "notas completamente biográficas" compóem uma personagem de si própria, reconfigurando e reambientando sua vida empírica no universo ficcional, afinal, de acordo com Diana Klinger, "o que interessa na autoficção não é a relação do texto com a vida do autor, e sim a do texto como forma de criação de um mito, o mito de escritor" (KLINGER, 2007, p. 50). Reinventando-se, Mariana Bernardes oferece a seus leitores uma imagem construída discursivamente, suficiente para desvinculá-la de sua vida empírica, mas, apesar de possuir Facebook, como Nazarian, Cuenca, Ivana e Averbuck, ainda está longe do reconhecimento público de ser uma escritora, pois falta-lhe a circulação na grande mídia, uma das grandes fontes de legitimação autoral. Isso não a impede, porém, de prosseguir investindo em sua performance: inicia explicando-se melhor e finaliza fingindo ser o que não é.

Para quem acredita que o escritor deve ser sem-vergonha, ou seja, não deve recear a exposição textual, a autora, em post intitulado "Débil catarse", publicado no dia 2 de maio de 2013, revela seu desconforto mediante uma crítica sofrida. O texto, todos sabemos, uma vez publicado, ganha autonomia e foge do controle de seu autor; cada leitor terá uma interpretação e o recepcionará de formas diversas; críticas positivas e negativas fazem parte do universo do escritor e, para dele fazer parte, é mister saber recebê-las. Neste post, Mariana comenta como se frustrou com um comentário pejorativo de um leitor. Da euforia advinda com a notícia da publicação, rapidamente passou à decepção das duas únicas palavras que seu crítico escreveu - e que intitularam o post: "débil catarse". Se por um lado a blogueira, inicialmente, reagiu mal à crítica, por outro, na segunda parte do post, demonstrou amadurecimento:

Se eu tivesse um espelho naquele momento aposto que meu rosto pareceria estar derretendo de desgosto. Quer dizer então que escrevi um texto débil? De acordo com o leitor, sim.

Primeiro o xinguei mentalmente apenas para perceber que cada um tem direito à sua opiniáo, que talvez o texto náo passasse mesmo de um desabafo desorganizado e que essa crítica poderia vir a me ajudar. Normalmente o que me causa desconforto é o que mais me ajuda, e eu sei como esse comentário me causou desconforto. 
O que percebo é que escrevo para pessoas. Deixei de escrever só para mim quando fiz um blog e comecei a mandar meus textos para revistas, jornais e editoras. Opinióes chegarão e isso é bom, quer dizer que pelo menos alguém lê minhas débeis catarses. Ainda tenho muito que aprender e sei bem que o caminho para onde quero chegar como escritora é longo, talvez mais do que imagino, porém uma crítica que não me agrada e não me faz virar o Pavão que sou me ajuda muito mais que elogios.

A partir de agora fico mais atenta às debiloidices que decido escrever e principalmente publicar. Com exceção desta que aqui posto, é claro.

A consciência de que escreve para pessoas e que as críticas podem lhe ajudar veio em um bom momento, exatamente a 26 dias do lançamento de seu primeiro livro, Demasias. Uma semana antes, porém, ela escreve sobre suas expectativas para a estreia. A inquietação da autora debutante remete ao terreno do desconhecido, haja vista que a publicação e a recepção textuais na internet são já conhecidas, mas as mesmas em edição impressa, para um autor inédito, são incertas. Além disso, considerando a legitimidade conferida ao livro, seu insucesso seria muito mais severo, implacável.

Curiosamente, após o lançamento de Demasias, Mariana Bernardes publicou apenas um post em seu blog, no dia 14 de junho de 2013 - trata-se de outra poesia, "Remédio", título bastante sugestivo. Em contato com a autora, fui informado de que ela está dando um tempo para que as ideias se arrumem novamente (sic).

Seja qual for o motivo da pausa momentânea na atualização do Resultado Desastroso, vale a reflexáo de que a literatura continua a ser escrita de forma cada vez mais frequente e democrática. A respeito da crítica conservadora de que blogs não devem ser considerados literatura, penso que esse estigma, senão imediatamente, em breve será superado. As crônicas também já foram estigmatizadas como escrita descartável e meramente referencial. O desassossego de Clarah Averbuck em defender uma coletânea de posts pode ser justificado com as inúmeras antologias de crônicas publicadas e referendadas como de clara qualidade literária - e boa parte delas, senão todas, escritas, originalmente, em jornais, um veículo menos nobre, literariamente, do que 
o livro, como hoje ocorre com os blogs. Podemos estender o estranhamento, desconforto e resistência a novas formas textuais para além das crônicas. Em busca do tempo perdido, de Proust, e Memorial de Aires, de Machado, são dois exemplos de obras-primas que tiveram um recepção controversa em função da inadequação à produção canônica de então, para citarmos apenas dois casos. Já deve ser hora de analisarmos a recorrente escrita blogueira com outros olhos, mais interessados em discutir a literatura deste século levando-se em conta seu contexto sociocultural. Mais que desqualificar os blogs, faz-se necessário compreender quais as alteraçôes literárias decorrentes desse novo meio de publicação e como este dialoga com a publicação impressa, pois há muitos pontos em comum.

\section{Referências:}

ARFUCH, Leonor. O espaço biográfico: dilemas da subjetividade contemporânea. Tradução de Paloma Vidal. Rio de Janeiro: EdUERJ, 2010.

AVERBUCK, Clarah. https://www.facebook.com/averbuck?fref=ts. Acesso em 30 de julho de 2013.

. Importa o que está escrito. Disponível em: http://www.osarmenios. com.br/2007/10/\%E2\%80\%9Cimporta-o-que-esta-escrito\%E2\%80\%9D-entrevista-com-clarah-averbuck/. 22 out. 2007. Entrevista concedida a Fabíola Hauch e Rodrigo de Andrade. Acesso em 10 de janeiro de 2010.

- Personagem de si mesma. Disponível em: http://wwwb.click21. mypage.com.br/MyBlog/visualiza_blog.asp?site=clickinversos.myblog.com. br\&primpost $=\mathrm{m} 52 \mathrm{Tk} 87 \mathrm{Jje} 4 \mathrm{go} 30 \mathrm{em} 8 \mathrm{IT} 7104172728 \mathrm{IRYHH} 3 \mathrm{H} 0 \mathrm{PF} \&$ infra me $=$ T. 4 out. 2007. Entrevista concedida a Ramon Mello. Acesso em 10 de janeiro de 2010.

AZEVEDO, Luciene. Blogs: a escrita de si na rede dos textos. Matraga, Rio de Janeiro, ano 14, n.21, p. 44-55, jul./dez. 2007.

BARTHES, Roland. A morte do autor e Da obra ao texto In: . O rumor da língua. São Paulo/ Campinas: Brasiliense/ Ed. Da Unicamp, 1988, p. 65-78. BENJAMIN, Walter. Magia e Técnica, arte e politica: ensaios sobre literatura e história da cultura. Tradução de Sergio Paulo Rouanet. São Paulo: Brasiliense, 1994. (Obras escolhidas; vol. I). 
BERNARDES, Mariana. Resultado Desastroso. Disponível em http://resultadodesastroso.blogspot.com.br/. Acesso em 5 de agosto de 2013.

2013.

. https://www.facebook.com/mdabernardes. Acesso em 7 de agosto de

CUENCA, João Paulo. https://www.facebook.com/jpcuenca?fref=ts. Acesso em 30 de julho de 2013.

. Blog de anotaçóes por João Paulo Cuenca. Disponível em http:// oglobo.globo.com/blogs/cuenca/. Acesso em 30 de julho de 2013.

. J.P. Cuenca. Disponível em http://jpcuenca.com/. Acesso em 30 de julho de 2013.

. Blog do Cuenca. Disponível em http://blogdocuenca.blogspot.com. br/. Acesso em 30 de julho de 2013.

KLINGER, Diana Irene. Escritas de si, escritas do outro: o retorno do autor e a virada etnográfica. Rio de Janeiro: 7 Letras, 2007.

LEITE, Ivana Arruda. https://www.facebook.com/ivana.arrudaleite?fref=ts. Acesso em 30 de julho de 2013.

. Doidivanas. Disponível em http://doidivana.wordpress.com/. Acesso em 30 de julho de 2013.

LEJEUNE, Philippe. O pacto autobiográfico: de Rousseau à Internet. Tradução de Jovita Maria Gerheim Noronha e Maria Inês Coimbra Guedes. Belo Horizonte: Ed. UFMG, 2008.

LOPES, Denilson. No coração do mundo. Rio de Janeiro: Rocco, 2012.

NAZARIAN, Santiago. https://www.facebook.com/santiagonazarian?fref=ts. Acesso em 30 de julho de 2013.

. Jardim Bizarro. Disponível em http://www.santiagonazarian.blogspot.com.br/. Acesso em 30 de julho de 2013.

OLIVEIRA, Bruno Lima. A autofiç̧ão no campo da escrita de si: a construção do mito do escritor em Nove noites, de Bernardo Carvalho, e outros procedimentos autoficcionais na prosa brasileira contemporânea. 2010. 107f. Dissertação (Mestrado em Literatura Brasileira) - Instituto de Letras, Universidade do Estado do Rio de Janeiro, Rio de Janeiro. 
SÁ, Sérgio de. O escritor entrevistado: mass media e figurações. In: A reinvenção do escritor: literatura e mass media. Belo Horizonte: Ed. UFMG, 2010, p. 145-169.

SANTIAGO, Silviano. "Sentimento da vida, sentimento do mundo". Princeton, 2011 (Mimeo).

VIEGAS, Ana Cláudia. O "retorno do autor": relatos de e sobre escritores contemporâneos In: VALLADARES, Henriqueta Do Coutto Prado (org.). Paisagens ficcionais: perspectivas entre o eu e o outro. Rio de Janeiro: 7Letras, 2007.

\title{
STRATEGIES OF INSERT IN THE LITERATURE 2.0
}

\begin{abstract}
This essay aims to show some insertion strategies in the literary circuit by amateur young dilettantes. Until arriving the printed publication, and a supposed literary legitimacy of the writer, blogs are increasingly common serving as a literary exercise and insertion the author and text with the general public, as are examples Santiago Nazarian, João Paulo Cuenca, Ivana Arruda Leite and Clarah Averbuck.
\end{abstract}

KEYWORDS: Blog; literary circuit; autofiction.

Recebido em: 30/10/2014 Aprovado em: 20/02/2015 